\title{
THE UTILIZATION OF THE KINDS OF LIVE FOOD ON CLOWN LOACH FISH JUVENILES (Chromobotia macracanthus Bleeker)
}

\author{
Nina Meilisza"\#, Rina Hirnawati"), Sulasy Rohmy"), Agus Priyadi"), \\ and Jacques Slembrouck ${ }^{* *}$ \\ ") Research Institute for Ornamental Fish, Depok \\ *) Institute de Recherche pour le Developpment, France c/o Indonesia
}

(Received 11 April 2011 ; Accepted 14 June 2011 )

\begin{abstract}
Domestication and mass production technology of clown loaches fish have been developed by the Research Institute for Ornamental Fish Culture, Depok and the Institute de Recherche pour le Developpement (IRD). In the process, some constraints has been found and one of them was the cost of production and sustainable supply of Artemia as the only one of live food which used for clown loaches post-larvae until 2-3 months old juvenile. To solve this constraints, the use of other live feed as a substitute or replacement of Artemia should be applied, caused by it research of the utilization of the kinds of live food on clown loach juvenile need to be done. This research aims to determine the kinds of live food which be recommended for the substitution of Artemia on clown loaches fish juvenile (Chromobotia macracanthus Bleeker). Research carried out using 1 month old clown loach juveniles designed into the Complete Randomized Design in two factors namely are class of fish size $\mathrm{S}$ (35$50 \mathrm{mg}), \mathrm{M}(55-70 \mathrm{mg}), \mathrm{L}(75-90 \mathrm{mg})$ and the kinds of live food in the form of Artemia as a control, Moina, mini maggot, blood worms (Chironomus), and silk worms (Tubifex). Three levels treatment by class of fish size factor and five levels treatment by the kinds of live food factor produce 15 kinds of interactions with duplications. The research was conducted at recirculation system for 8 weeks to 3 months old juveniles. Observations were carried and measuring the growth parameters including weight, total length of fish, as well as survival rate parameters based on the number of fish that live at the end of the research. The support is done by measuring the water quality of $\mathrm{pH}, \mathrm{DO}$, temperature, ammonia, conductivity, and nitrites, proximate analysis of feed also performed. The two of research step analyzed by ANOVA (Analysis of Variance) and continued by Tukey test.
\end{abstract}

KEYWORDS: substitution feed, Artemia, 1 month old of clown loach juveniles

\section{INTRODUCTION}

Clown loaches fish or botia is one of the Indonesian original ornamental fish species that originated from Sumatra and Borneo and has a great potential as an export commodity because of the uniquely of shape and the beautifully of colors. The beautifull of the botia fish cause high economic value and aesthetic that has a broad market both domestic and abroad, but most botia fish production comes from the arrest in nature while the European market regulation recommends ornamental fish export products derived from aquaculture.

\# Corresponding author. Research Institute for Ornamental Fish, Jl. Perikanan No. 13, Pancoran Mas, Depok 411 52, West Java, Indonesia. Tel.: +62 217520482

E-mail address: sirunina@yahoo.com 
On the recent years, Research Institute for Ornamental Fish Culture, Depok and IRD (Institute de Recherche pour le Développement) has succeeded to the domestication and breeding technology of botia fish. The next challenge is to meet production demands both in quantity and quality. In the developmental process, the supply of juveniles to the export demand undertaken through mass production activities. In mass production, post-larval juveniles of botia fed with Artemia which is the only main feed for 1-3 months old. Since no artificial feed formulation is yet available to completely substitute for Artemia, feeding live prey to young fish larvae still remain essential in commercial hatchery operations (Sorgeloos et al., 2001). Consideration of feeding is due at the beginning of exogenous feeding, small live food such as Artemia nauplii more appropriate caused by the fish have difficulty in assimilating with a form of artificial dry feed (Hogendoorn, 1979).

The constraints then occur due to the continuity and production costs are relatively high because of known feed Artemia has absorbed much of the aquaculture cost of total production. Furthermore, the high price of Artemia cysts has increased the fish production cost, and cheaper alternative diets with comparable nutritional quality are needed to maintain the cost competitiveness of ornamental fish in the global market (Lim et al., 2003).

The constraints then occur due to the continuity and production costs are relatively high because of known feed Artemia has absorbed much of the aquaculture cost of total production. Reduction of Artemia in feed of aquaculture is considered advantageous because of high costs can be lowered so did the complexity of the culture that accompanies it (Gonzalez et al., 2008 in Chepkirui-boit, 2009). To apply the effectiveness and efficiently for rearing of juveniles, the using of other feed except Artemia as a food substitute or replacement needs to be conduct to answer the challenge of mass production that applied.

Zooplankton likes moina is an excellent protein source for aquaculture feeds, whether fed live or frozen to commercial fish species (Alam et al., 1993; Brett, 1971; Dabrowski, 1984; Kibria et al., 1999; Sargent et al., 1979; Yamasaki \& Uchiyama, 2001) in Ward \& Kumar (2010). Tubifex sp. is one of the best candi- dates for the following reasons: (i) it has a short generation time (42 days) on a single medium containing organic wastes like cow dung and coconut mesocarp and thus helps to abate the organic pollution of the medium, (ii) it occurs in a wide range of habitats and tolerates a spectrum of environmental variables, and (iii) it has a high fecundity of 92 to 340 eggs and reproduces within a temperature range of $0.5^{\circ} \mathrm{C}-30^{\circ} \mathrm{C}$ (Brinkhurst \& Kennedy, 1965; Birtwell \& Arthur, 1980; Kaster, 1980), Poddubnaya (1980) in Marian \& Pandian (1984). While maggot is a larvae of Black Soldier fly that recommended for live food cause has many advantages in aquaculture as a bioconversion product and the culture had been handled by a lot of Indonesian fish farmer.

Since the quantity of feed in the experiments was not limiting, these findings suggested that the quality of a starter feed was crucial to the later stages of development. Fish that were fed sub-optimally in the early stage would continue to suffer from poor performance later (Lim et al., 2003).

Unknowing the kinds and amount of live food as a substitute for proper Artemia feed on botia juveniles on 1 month old of led to the need for this research. Therefore, research of substitute Artemia on 1 month old of botia juveniles expected to answer the problems that exist and can be used to reduce of costs and increasing of production and can be applied by the farmers.

\section{MATERIALS AND METHODS}

This research aimed to determine the best kinds of live food for growth and survival for 1 month old of botia juveniles. The live food which used are five kinds of live food was applied to the juveniles of ornamental fish included Artemia itself as Moina, Chironomus, maggot, and Tubifex. The best kinds of live food that will be produced recommended to substitute of Artemia.

This research uses botia juveniles fish on age of 1 month old by stocking five fish per liter. The juveniles of botia sorted into 3 sizes of size $S$ ( $35-50 \mathrm{mg}), \mathrm{M}(55-70 \mathrm{mg}), \mathrm{L}(75-90 \mathrm{mg})$. In this preliminary research the juveniles of botia provided Artemia as a control diet and the other live food are Moina, mini maggot, blood worms (Chironomus), and silk worm (Tubifex). Two levels factor of 3 size of juveniles and 5 kinds of live food are designed in a 
factorial design and each one is duplicates. Design a preliminary research to follow of Table 1.

Fed was delivered 4 times a day at 08.00, $11.00,14.00$, and 17.00. Specific studies on this topic (González et al., 2009; Sáez-Royuela et al., 2001) in Ganzalez et al. (2009) have shown that an increase in food supply frequency from once to twice a day do not improve growth figures, so this experiments planned for four times fed a day to give the better performance. Based on the feeding behavior of botia juveniles that continuously eating during the fed time, the food provided on ad satiation by indicators of any kinds of feed is almost over at the next fed time. The sampling was done every 2 weeks during research. The research will be done until the age of juveniles reach on 3 months old. The other measurements as the supporting data also conducted, that are water quality and feed proximate analysis. Water quality to be measured are $\mathrm{pH}, \mathrm{DO}$, ammonia, conductivity, and nitrites. Proximate analysis of feed in the form of dry matters, protein content, fat, carbohydrates, crude fiber, and ash.

Sampling was done by measuring the weight of the fish biomass and total length of fish. The measurement of weight of fish is done

Table 1. Treatments by size of fish and the kinds of live feeds

\begin{tabular}{ccc}
\hline Treat ment & $\begin{array}{c}\text { Size of } \\
\text { fish }\end{array}$ & $\begin{array}{c}\text { The kinds of live } \\
\text { feed }\end{array}$ \\
\hline SA & S & Artemia \\
BC & S & Moina \\
SG & S & Mini maggot \\
ST & S & Tubifex \\
SC & S & Chironomus \\
MA & M & Artemia \\
MM & M & Moina \\
MG & M & Mini maggot \\
MT & M & Tubifex \\
MC & M & Chironomus \\
LA & L & Artemia \\
LM & L & Moina \\
LG & L & Mini maggot \\
LT & L & Tubifex \\
LC & L & Chironomus \\
\hline
\end{tabular}

by using a digital balance with accuracy of $0.001 \mathrm{~g}$ while the length measurement is done by taking photos of fish in the millimeter blocks and measured by IMAGEJ software program. The weight per individual measurement was performed at initial and end of research, while the survival rate was calculated at the end of the research.

The data results obtained from measurements of growth and survival parameters then were analyzed by using of ANOVA statistical analysis (Analysis of Variance) and if known there has influence of further treatment followed by Tukey test. The kinds of live food that produces best growth and survival then became to the recommendation for use on substitution feed.

\section{RESULTS AND DISCUSSION}

The research that aimed to determine the best kinds of live food that will be recommended as a substitution feed has resulted data of the growth and survival based on parameters that have been measured as set out in Table 2.

Table 2 shows that the interactions treatment between fish size and different kinds of live food provides a significantly influence on the growth of weight gain and specific growth rate $(P<0.05)$. The significant differences can be seen from the range differentiating of the level significantly.

The highest of weight gain generated by LT treatment (fish size L; live food Tubifex) with the increase in weight reaching $1.125 \mathrm{~g}$ followed by the MT treatment (fish size M; live food Tubifex) amounted to $0.0983 \mathrm{~g}$ and ST treatment (fish size S; live food Tubifex) of $0.927 \mathrm{~g}$ and all three are on the same level or not significantly different from each other but significantly different from other treatments. Treatment LG, SG, and MG of fish size L, S, and $M$ to the kinds of live food on maggot is a treatment that produces the lowest weight gain that they also are on the same level or not significantly different from each other but significantly different from other treatments.

In addition to the weight gain, specific growth rate is also influenced by fish size and kinds of live food with a range of differentiating on the level significantly. The highest of specific growth generated by the treatment ST, MT, and LT in a row with a value of $5.66 \%$, 
Table 2. Initial weight (g), weight gain (g), and specific growth rate (\%) of botia juveniles on three classes of fish size given by the kinds of live feeds during eight weeks of research period

\begin{tabular}{cccccc}
\hline $\begin{array}{c}\text { Class of } \\
\text { fish size }\end{array}$ & Live feeds & Treatment s & $\begin{array}{c}\text { Initial weight } \\
(\mathbf{g})\end{array}$ & $\begin{array}{c}\text { Weight gain } \\
(\mathbf{g})\end{array}$ & $\begin{array}{c}\text { Specific growth } \\
\text { rate } \mathbf{( \% )}\end{array}$ \\
\hline S & Artemia & SA & $0.039 \pm 0.001$ & $0.645 \pm 0.038^{\mathrm{bcde}}$ & $5.10 \pm 0.07^{\mathrm{ab}}$ \\
& Tubifex & ST & $0.040 \pm 0.001$ & $0.927 \pm 0.175^{\mathrm{ab}}$ & $5.66 \pm 0.35^{\mathrm{a}}$ \\
& Chironomus & SC & $0.039 \pm 0.000$ & $0.629 \pm 0.007^{\mathrm{bcde}}$ & $5.07 \pm 0.01^{\mathrm{ab}}$ \\
& Moina & BC & $0.041 \pm 0.001$ & $0.350 \pm 0.016^{\mathrm{ef}}$ & $4.03 \pm 0.12^{\mathrm{cdef}}$ \\
& Maggot & SG & $0.039 \pm 0.001$ & $0.194 \pm 0.002^{\mathrm{f}}$ & $3.17 \pm 0.04^{\mathrm{fg}}$ \\
\hline M & Artemia & MZ & $0.061 \pm 0.001$ & $0.806 \pm 0.201^{\mathrm{abcd}}$ & $4.71 \pm 0.40^{\mathrm{bc}}$ \\
& Tubifex & MT & $0.062 \pm 0.000$ & $0.983 \pm 0.050^{\mathrm{ab}}$ & $5.03 \pm 0.09^{\mathrm{ab}}$ \\
& Chironomus & MC & $0.062 \pm 0.000$ & $0.747 \pm 0.023^{\mathrm{abcd}}$ & $4.58 \pm 0.06^{\mathrm{bc}}$ \\
& Moina & MM & $0.060 \pm 0.002$ & $0.413 \pm 0.006^{\mathrm{def}}$ & $3.68 \pm 0.02^{\mathrm{def}}$ \\
& Maggot & MG & $0.063 \pm 0.001$ & $0.186 \pm 0.040^{\mathrm{f}}$ & $2.45 \pm 0.31^{\mathrm{gh}}$ \\
\hline \multirow{2}{*}{ L } & Artemia & LA & $0.081 \pm 0.001$ & $0.849 \pm 0.256^{\mathrm{abc}}$ & $4.31 \pm 0.51^{\mathrm{bcde}}$ \\
& Tubifex & LT & $0.083 \pm 0.001$ & $1.125 \pm 0.029^{\mathrm{a}}$ & $4.79 \pm 0.05^{\mathrm{abc}}$ \\
& Chironomus & LC & $0.082 \pm 0.001$ & $0.861 \pm 0.044^{\mathrm{abc}}$ & $4.37 \pm 0.11^{\mathrm{bcd}}$ \\
& Moina & LM & $0.082 \pm 0.001$ & $0.477 \pm 0.031^{\mathrm{cdef}}$ & $3.43 \pm 0.09^{\mathrm{ef}}$ \\
& Maggot & LG & $0.081 \pm 0.001$ & $0.210 \pm 0.039^{\mathrm{f}}$ & $2.27 \pm 0.23^{\mathrm{h}}$ \\
\hline
\end{tabular}

Note: The same alphabet on the same column means not significantly different $(P>0.05)$

$5.03 \%$, and $4.79 \%$ where all three treatments were equally live food Tubifex with class sizes $\mathrm{S}, \mathrm{M}$, and $\mathrm{L}$. The three treatment shows that the value was not significantly different from each other but significantly different from other treatments. The lowest specific growth rate shown by the treatment of live food maggot succession on fish size classes $\mathrm{S}, \mathrm{M}$, and $\mathrm{L}$ at $3.17 \%, 2.45 \%$, and $2.17 \%$ of the three were not significantly different from each other but significantly different with other treatments.

From the above data, when lowered into the graph it is obvious that the greater absolute weight growth linear with the larger size classes of fish. The growth of weight gain, respectively from highest to lowest was produced by the treatment of the kinds of live food Tubifex, Artemia, Chironomus, Moina, and then maggot. This performance applies to all fish size classes $S, M$, and L (Figure 1).

The graph in Figure 2 shown that the specific growth rate decreased with increasing fish size class. In this graph, the highest specific growth rate to the lowest in a row resulted by fish size class $\mathrm{S}$ and followed by $\mathrm{M}$ and the last by L. While the kinds of live food that produces the highest specific growth rate to the lowest in a row indicated by the Tubifex, Artemia, Chironomus, Moina, and maggot. This also applies to all size classes of fish.

The almost similar case occurs on the experiments of Pangasius bocourti were carried out to evaluate of larval rearing with different feeding regimes of Artemia, Tubifex, and Moina. Result showed that, survival rates of larvae fed on Artemia nauplii, cladocereans (Moina sp.), orred-bloodworms (Tubifex) were not significantly different, 91\%-93\%. Artemia nauplii and Tubifex gave similar growth rates (35\%-36 \% day ${ }^{-1}$ ) while Moina sp. resulted in lower growth (Hung et al., 1999). Its indicated that Moina gave the lowest growth than Tubifex and Artemia.

In the graphs in Figures 1 and 2 when compared on the basis of class size, it can be concluded that the growth performance of the absolute seed weight botia contrary to the specific growth rate. Growth will increase the absolute weight on the fish size classes greater botia $(\mathrm{S}<\mathrm{M}<\mathrm{L})$, while the specific 


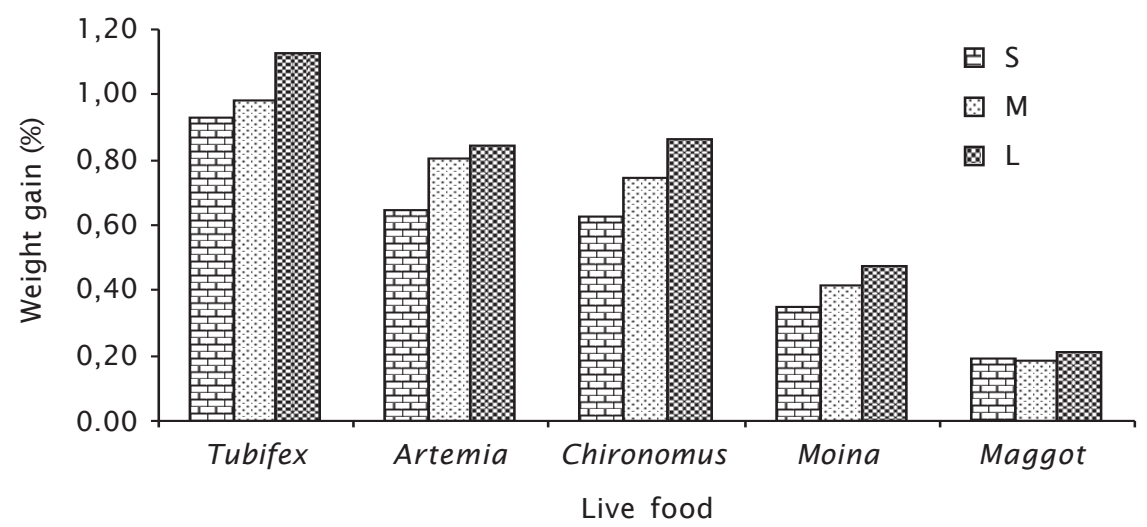

Figure 1. Weight gain (g) on botia juveniles in three size classes $(\mathrm{S}, \mathrm{M}, \mathrm{L})$ and the kinds of live food

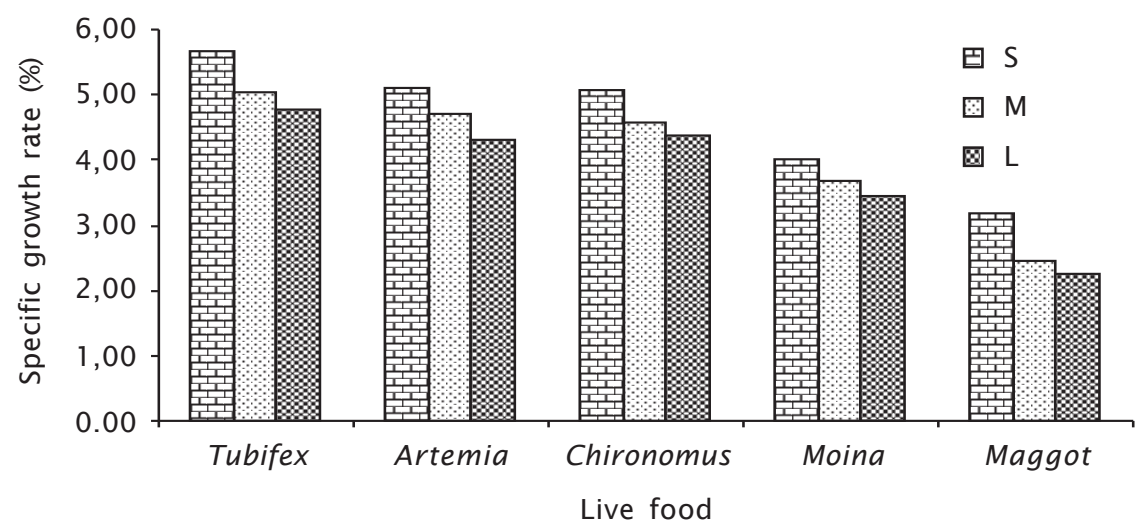

Figure 2. Specific growth rate (\%) on botia juveniles in three size classes (S, M, L) and the kinds of live food

growth rate will further decline in fish size classes greater $(\mathrm{S}>\mathrm{M}>\mathrm{L})$.

The different case shown if the graphs in Figures 1 and 2 compared based on their kinds of live food, the performance generated by the growth in weight gain and specific growth rate shows the similar describe. The both of figure shows the gratest kinds of live food that generate the highest value to lowest in a row that is Tubifex, Artemia, Chironomus, Moina, and maggot.

Table 3 shows that there is a treatment effect of fish size and kinds of live food on the growth of length gain. The length gain value relatively was not significant different between treatment the kinds of live food Artemia, Tubifex, and Chironomus but quite significant when compared with the treatment Moina and maggot. The treatment of Tubifex produced the highest growth of length gain than any other live food, while maggot results the lowest growth of length gain than any other live food and occured in all of fish size classes S, M, and L.

Survival rates in each treatment fish size and kinds of live food shows not significantly different $(P>0.05)$. This indicates that all of live food able to maintain of botia juveniles viability until it reaches almost $100 \%$. Besides influenced by the kinds of live food, a high survival rate was also allegedly influenced by the water quality which is still within the normal range and not harmful to the botia juveniles. The range value of water quality can be seen in Table 4. 
Table 3. Initial length ( $\mathrm{mm}$ ), length gain (g), and survival rate (\%) of botia juveniles on three classes of fish size and the kinds of live food during eight weeks of research period

\begin{tabular}{cccccc}
\hline $\begin{array}{c}\text { Class of } \\
\text { fish size }\end{array}$ & $\begin{array}{c}\text { Live } \\
\text { feeds }\end{array}$ & Treat ment s & $\begin{array}{c}\text { Initial length } \\
(\mathbf{m m})\end{array}$ & $\begin{array}{c}\text { Length gain } \\
\mathbf{( m m})\end{array}$ & $\begin{array}{c}\text { Survival rate } \\
(\%)\end{array}$ \\
\hline S & Artemia & SA SA & $14 \pm 1$ & $21 \pm 2^{\mathrm{abc}}$ & $98 \pm 2.8^{\mathrm{a}}$ \\
& Tubifex & ST ST & $14 \pm 1$ & $23 \pm 2^{\mathrm{abc}}$ & $100 \pm 0.0^{\mathrm{a}}$ \\
& Chironomus & SC SC & $14 \pm 1$ & $20 \pm 2^{\mathrm{abc}}$ & $100 \pm 0.0^{\mathrm{a}}$ \\
& Moina & SM BC & $14 \pm 1$ & $18 \pm 1^{\mathrm{c}}$ & $92 \pm 5.7^{\mathrm{a}}$ \\
& Maggot & SC SG & $14 \pm 1$ & $11 \pm 1^{\mathrm{d}}$ & $90 \pm 8.5^{\mathrm{a}}$ \\
\hline M & Artemia & MA MA & $16 \pm 1$ & $19 \pm 1^{\mathrm{bc}}$ & $98 \pm 2.8^{\mathrm{a}}$ \\
& Tubifex & MT MT & $16 \pm 1$ & $25 \pm 1^{\mathrm{a}}$ & $98 \pm 2.8^{\mathrm{a}}$ \\
& Chironomus & MC MC & $16 \pm 1$ & $22 \pm 1^{\mathrm{abc}}$ & $100 \pm 0.0^{\mathrm{a}}$ \\
& Moina & MM MM & $16 \pm 1$ & $18 \pm 3^{\mathrm{c}}$ & $100 \pm 0.0^{\mathrm{a}}$ \\
& Maggot & MG MG & $16 \pm 1$ & $11 \pm 1^{\mathrm{d}}$ & $98 \pm 2.8^{\mathrm{a}}$ \\
\hline \multirow{2}{*}{ L } & Artemia & LA LA & $18 \pm 1$ & $24 \pm 0^{\mathrm{ab}}$ & $98 \pm 2.8^{\mathrm{a}}$ \\
& Tubifex & LT LT & $18 \pm 1$ & $23 \pm 1^{\mathrm{ab}}$ & $100 \pm 0.0^{\mathrm{a}}$ \\
& Chironomus & LC LC & $18 \pm 1$ & $22 \pm 2^{\mathrm{abc}}$ & $100 \pm 0.0^{\mathrm{a}}$ \\
& Moina & LM LM & $18 \pm 1$ & $19 \pm 1^{\mathrm{bc}}$ & $98 \pm 2.8^{\mathrm{a}}$ \\
& Maggot & LG LG & $18 \pm 1$ & $10 \pm 0^{\mathrm{d}}$ & $98 \pm 2.8^{\mathrm{a}}$ \\
\hline
\end{tabular}

Note: The same alphabet on the same column means not significantly different $(P>0.05)$

Table 4. The range data of water quality on treatments by three class of fish size and the kinds of live feed

\begin{tabular}{ccccccc}
\hline & \multicolumn{6}{c}{ Parameters } \\
\cline { 2 - 7 } Treat ment s & $\begin{array}{c}\text { Temperat ure } \\
\left({ }^{\circ} \mathbf{C}\right)\end{array}$ & $\mathbf{p H}$ & $\begin{array}{c}\text { Oxygen } \\
(\mathbf{m g} / \mathbf{L})\end{array}$ & $\begin{array}{c}\text { Conductivity } \\
(\boldsymbol{\mu S})\end{array}$ & $\begin{array}{c}\mathbf{N} \text {-ammonia } \\
(\mathbf{m g} / \mathrm{L})\end{array}$ & $\begin{array}{c}\text { N-nit rit e } \\
(\mathbf{m g} / \mathrm{L})\end{array}$ \\
\hline SA & $27.6-28.8$ & $7.22-7.70$ & $6.04-6.67$ & $421.6-441.0$ & $0.000-0.005$ & $0.000-0.065$ \\
SM & $27.6-29.0$ & $7.21-7.67$ & $6.00-6.73$ & $430.0-446.7$ & $0.000-0.002$ & $0.000-0.021$ \\
SG & $27.7-29.0$ & $7.30-7.71$ & $6.01-6.78$ & $429.1-452.0$ & $0.000-0.001$ & $0.000-0.011$ \\
ST & $27.6-28.8$ & $7.26-7.73$ & $6.22-6.87$ & $432.8-446.9$ & $0.000-0.005$ & $0.000-0.011$ \\
SC & $27.7-29.1$ & $7.32-7.68$ & $6.20-6.71$ & $430.2-447.8$ & $0.000-0.002$ & $0.000-0.016$ \\
MA & $27.8-29.1$ & $7.30-7.71$ & $6.34-6.66$ & $425.8-439.8$ & $0.000-0.004$ & $0.000-0.060$ \\
MM & $27.6-28.7$ & $7.29-7.66$ & $6.30-6.82$ & $422.7-446.7$ & $0.000-0.002$ & $0.000-0.025$ \\
MG & $27.6-28.8$ & $7.23-7.68$ & $6.04-6.75$ & $430.1-449.0$ & $0.000-0.001$ & $0.000-0.011$ \\
MT & $27.7-28.8$ & $7.22-7.70$ & $6.05-6.88$ & $431.1-444.5$ & $0.000-0.004$ & $0.000-0.010$ \\
MC & $27.6-28.7$ & $7.21-7.67$ & $6.11-6.56$ & $432.0-445.6$ & $0.000-0.002$ & $0.000-0.017$ \\
LA & $27.7-29.0$ & $7.30-7.71$ & $6.29-6.74$ & $429.8-443.2$ & $0.000-0.005$ & $0.000-0.059$ \\
LM & $27.7-29.1$ & $7.26-7.73$ & $6.00-6.70$ & $429.1-452.0$ & $0.000-0.002$ & $0.000-0.021$ \\
LG & $27.8-28.9$ & $7.32-7.68$ & $6.22-6.87$ & $430.2-447.8$ & $0.000-0.001$ & $0.000-0.011$ \\
LT & $27.8-28.8$ & $7.26-7.73$ & $6.20-6.71$ & $430.0-446.7$ & $0.000-0.005$ & $0.000-0.016$ \\
LC & $27.6-29.0$ & $7.32-7.68$ & $6.04-6.75$ & $429.1-452.0$ & $0.000-0.001$ & $0.000-0.016$ \\
\hline
\end{tabular}


The graph in Figure 3, the average of individual weight of botia juvenile increased each week. This increase shows the daily growth continued linearly during research period. The graph indicates that all of botia fish size on classes S, M, or L to increase the weight weekly with the same pattern. The increase in weight continued to increase in each class of fish size. The average of individual weight on the graph shows that the kinds of live food Tubifex increased to a larger and faster compared with other live treatments on each week. The kinds of live food Artemia and Chironomus tends to result increases weights performance relatively almost similar or not significant among the both and occurs every week on all classes of fish size. This is indicated by a nearly linear overlap line among the both. While Moina and maggot showed the increase the lowest on average individual weight compared to third other kinds of live food and consistently occurred in each class of fish size.

The graph in Figure 4 shows that the specific growth rate will be decline as long as research period. The decrease of specific growth rate occurred on all classes of fish size that shown by the picture above. This decrease occurs because the specific growth rate is influenced by the variables of time in which the specific growth rate per week is the result by calculation of the difference between the sampling time and the initial time.

From the graph it is estimated that the longer term of research period accordingly of the specific growth rate will be lower if calculated from the nitial time. The same as average of individual weight weekly, specific growth rate also showed that Tubifex generate the highest value compared to other kinds of live food. The kinds of live food that produces the highest to lowest of specific growth rate to the lowest on each week in a row that is Tubifex, Artemia, Chironomus, Moina, and maggot. Performance is consistently occurred in all classes of fish size.

From the picture of an average individual weight and specific growth rate per week were known that there is no different performance in each class of fish size and significant effect due to the given of different kinds of live food. The differences of growth performance caused by different kinds of live food, its occurs because the content of nutrients contained in each kinds of live food is different. Nutritional value of the five live food used in this research are presented in Table 5.

In accordance Mudjiman (2004) fish need nutrients used as energy source for growth and daily activities, because the feed must contain energy-producing substances such as proteins, lipid, and carbohydrates. In addition, the feed should also contain vitamins, minerals, fiber, and water that used for other physiological processes. The five live food that used in this research could be expected to provide energy and growth of botia juveniles, the nutritional content has been analyzed as indicated in Table 5.

Table 5 shows that the content of nutrients in the four kinds of live food that is Moina, Tubifex, Chironomus, and Artemia has almost the similar of moisture content while the maggot tend relatively has the lower of water content. The highest protein content found on Tubifex, Chironomus, Artemia, maggot, and the lowest is Moina. On the five kinds of live food, maggot and Artemia tend to have the higher of lipid compared than the other three kinds of live food.

From the nutritional content listed known that Tubifex has about $67 \%$ protein content and higher than any others live food, while Moina has the lowest protein content is about $37 \%$. Blood worms or Chironomus has about 3\% excess of protein content compared with Tubifex and also has the lowest energy value compared to others live food. Although the structure and form of Chironomus almost similar with Tubifex but Chironomus has a weakness as a live food because of its availability is only available in frozen form and its make the freshness is reduced and prone to lysis and loss of nutritional content when being in the water.

The protein quality of feed is to support the growth including the formation of body tissues. Food that has a high protein content is not necessarily to accelerate of growth if the feed energy total is low because the feed energy used for activities prior of standard metabolism, specific dynamic action (the digestive process) and physical activity (Effendi, 1997). This is reflected in the botia juveniles that fed Chironomus which has about 64\% protein and $19.91 \mathrm{MJ} / \mathrm{kg}$ energy, the growth that occurs lower than Artemia which contains about $57 \%$ protein and of $22.06 \mathrm{MJ} / \mathrm{kg}$ energy. 

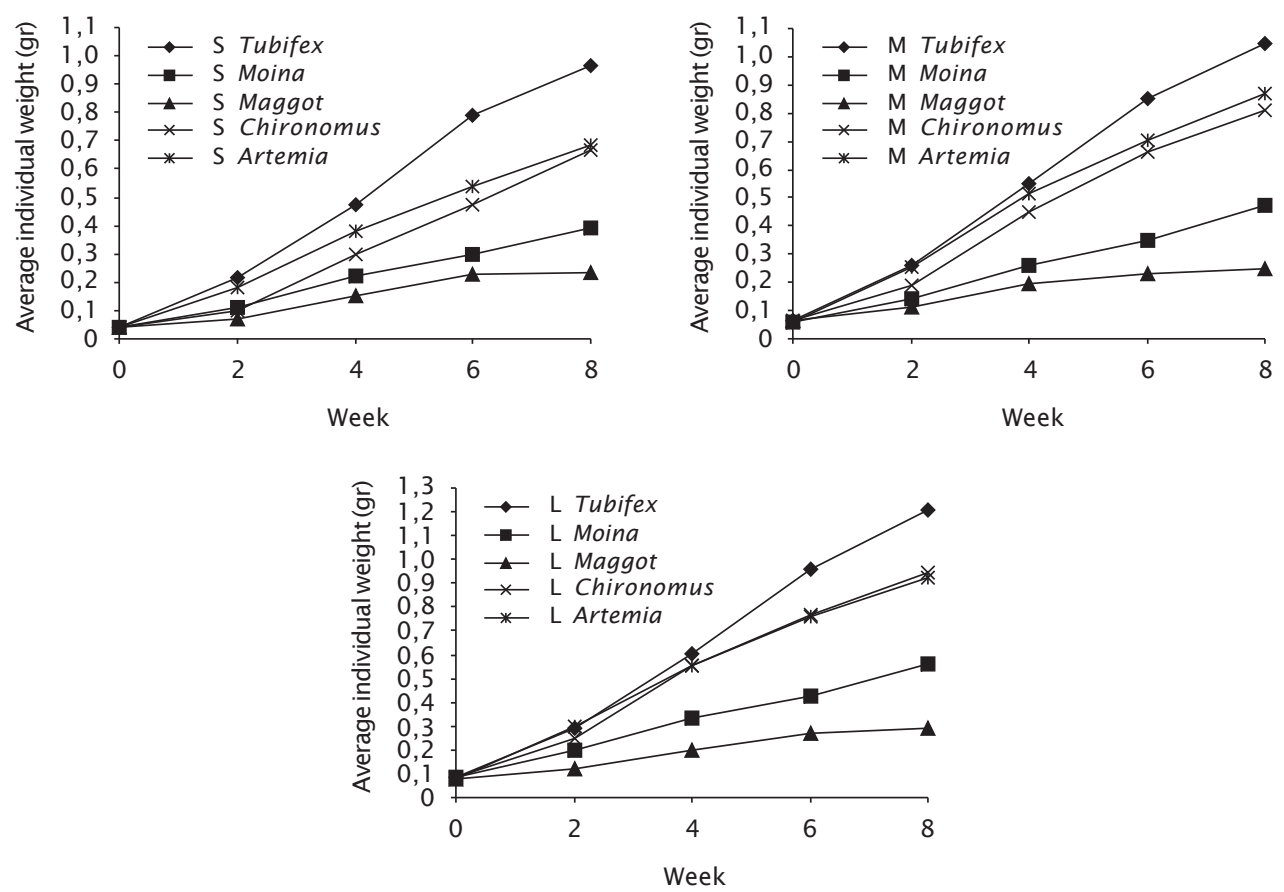

Figure 3. Average individual weight $(\mathrm{g})$ botia juveniles on three of the class of fish size and the kinds of live feeds during eight weeks of research period
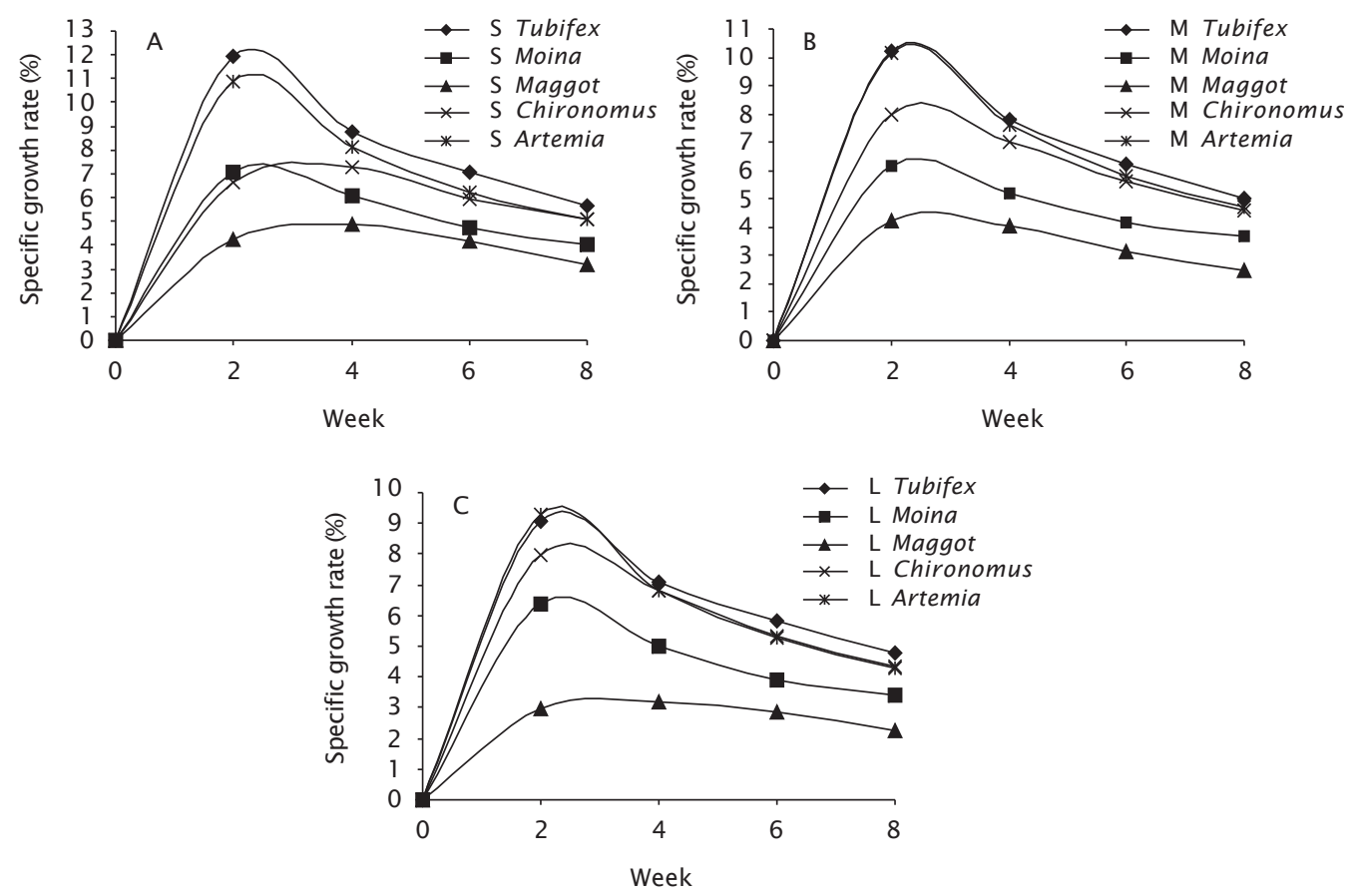

Figure 4. Specific growth rate (\%) botia juveniles on three classes of fish size (a) S, (b) M, (c) L and the kinds of live feeds during eight weeks of research period 
Table 5. Result of proximate analysis on the kinds of live feed

\begin{tabular}{lcccccc}
\hline \multirow{2}{*}{ Sample } & $\begin{array}{c}\text { Moist ure } \\
(\%)\end{array}$ & $\begin{array}{c}\text { Protein } \\
\text { (\%) }\end{array}$ & $\begin{array}{c}\text { Fat } \\
(\%)\end{array}$ & $\begin{array}{c}\text { Ash } \\
(\%)\end{array}$ & $\begin{array}{c}\text { NFE } \\
(\%)\end{array}$ & $\begin{array}{c}\text { Energy } \\
\text { (MJ/kg) }\end{array}$ \\
\hline Moina & 90.60 & 37.38 & 13.29 & 11.00 & 38.33 & 20.66 \\
Tubifex & 87.73 & 66.94 & 9.44 & 5.33 & 18.29 & 22.67 \\
Chironomus & 89.89 & 64.01 & 5.72 & 15.50 & 14.77 & 19.91 \\
Artemia & 89.56 & 57.48 & 21.34 & 20.78 & 0.40 & 22.06 \\
Maggot & 60.80 & 42.07 & 24.50 & 11.36 & 22.07 & 23.40 \\
\hline
\end{tabular}

Note: Sample in dry matter, NFE (Nitrogen Free Extract) $=100$ - sum (crude protein, ether extract, fibre, ash); Gross energy: calculated 23.6, 39.5, and $17.2 \mathrm{~kJ} \mathrm{~g}^{-1}$ for protein, lipid, and NFE, respectively (N.R.C., 1993)

Based on consideration of the use of food by Effendi (2004) that feed used should be small, smaller than the opening mouth of the fish, moving for easily detected and eaten by the larvae, easily digestible, and contain high nutrition, the five live food use in this research has met the requirements feed for botia juveniles. Kamal (1992) also added that botia fish can receive various kinds of food and the dominant foods that are most numerous in the stomach botia fish in a row is a group of crustaceans, insects, nematode, mollusk, algae, and unidentified material. However, feed requirements are also supported by other factors such as the ability of fish in the use of feed.

Moina, Artemia, and Chironomus relatively above the water surface tends to complicate botia fish to eat and changing his behavior. While the maggot even in the bottom waters but the protein content tended to be lower and more difficult to digest because of the presence of chitin inside. Chitin has a solid form and is not soluble in plain water or solvent. Chitin difficult to enzymatically hydrolyzed except using the chitinase enzyme (Yurnaliza, 2002). The nature of chitin in the maggot is what causes it difficult to digest in the digestive of botia little juveniles, which is reflected in this research where the dissected digestive tract of botia founded of maggot whole body in the intestine (Figure 5).

The highest growth rate produced by Tubifex allegedly not only caused by nutrient content inside but also due to the behavior living of Tubifex in the bottom waters. As Meilisza \& Hirnawati (2010) in the research of combination ratio of Tubifex and blood worms,

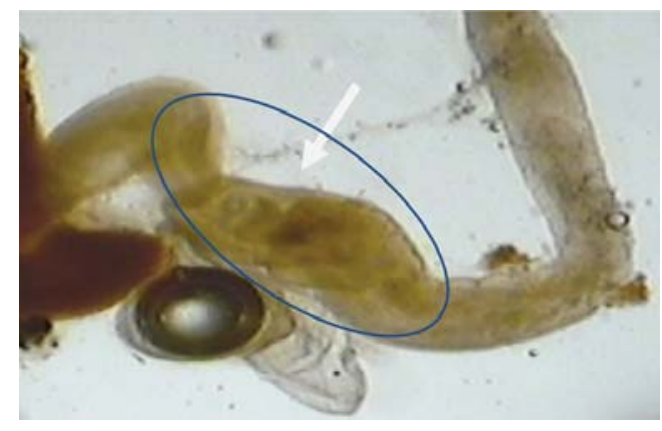

Figure 5. Fully of maggot in intestinal of botia juvenile. (Photo: personal doc.)

in the case of botia fish, Tubifex has other advantages compared with blood worms cause by it tends to be quiet and located in the bottom waters. The nature of the feed like this is preferred by the botia fish as the nature of life that habits and eating food in the bottom waters (bottom feeder). In addition to these advantages, Juhariyah (2005) also mentions another advantage of Tubifex that is high nutrient content and do not have a skeleton framework that is easily digested and very recommended for early weaning time of freshwater fish.

The quality of feed, age, and ability to take advantage of feed which then affect the performance of growth of juveniles botia and appropriate with the Huet (1994) opinion. There are two factors that influence to the growth of external factors and internal factors. External factors include environmental conditions and food quality. Internal factors are heredity, age, disease resistance, and ability to utilize feed. 
Allegations of this case is the nature of life, behavior and preferences to a feed to give a major influence on the growth of fish. This is in accordance with the Handayani (2006) opinion that a high quality fed and favored by fish other than to enhance the degree of utilization efficiency and also reinforce the growth and survival of fish. This conjecture is reinforced by Hepher \& Pruginin (1981) and Guillaume et al. (1999) which states that the factors that influence to the feed utilization is nutritional factors, environment, and fish behavior.

In the water quality data, water temperature within the range that are good for the life of tropical fish and it ranged $25^{\circ} \mathrm{C}-32^{\circ} \mathrm{C}$ (Mills \& Lamnert, 2004). In its natural habitat, botia fish live at temperatures $24^{\circ} \mathrm{C}-26^{\circ} \mathrm{C}$, but in the research of Mariyono \& Sugiyo in Sari (2003) botia fish that are kept in the aquarium grow optimally at temperature of $27^{\circ} \mathrm{C}-28^{\circ} \mathrm{C}$. While the $\mathrm{pH}, \mathrm{DO}$, nitrite, and ammonia are in good range for aquaculture organism (Effendi, 2003; Satyani, 2005). The scale of pH for live fish is generally a minimum of 4 and maximum 11 (Mulyanto, 1992). While the oxygen content for the maintenance of botia by Petrovsky (1988) can not be less than $3 \mathrm{mg} / \mathrm{L}$ because botia fish like area that has prosperous of oxygen. The data of water quality show that all physical and chemical parameters in each treatment were within the normal range and good for the survival or growth of botia (Table 4).

\section{CONCLUSIONS AND SUGGESTIONS}

The kind of live food which are recommended to substitute of Artemia at the age of 1 month botia juveniles is Tubifex. The use of Tubifex as food substitution of Artemia plays a role in the growth and survival of botia juveniles. The fed of Tubifex for botia growth compared to Artemia as a control diet may be considered not only as a substitution food but also as replacement food of Artemia.

\section{REFERENCES}

Alam, M.J., Ang, K.J., \& Cheah, S.H. 1993. Use of Moina micrura (Kurz) as an Artemia substitute in the production of Macrobrachium rosenbergii (de Man) post-larvae. Aquaculture, 109: 337-349.

Alam, M.J., Ang, K.J., \& Cheah, S.H. 1993. Weaning of Macrobrachium rosenbergii larvae from Artemia to Moina micrura. Aquaculture, 112: 187-194.

Ahamed, M.T., \& Mollah, M.F.A. 1992. Effects of various levels of wheat bran and mustard oil cake in the culture media on tubificid production. Aquaculture, 107: 107-113.

Anh, N.T.N., Hoa, N.V., Stappen, G.V., \& Sorgeloos, P. 2009. Effect of different supplemental feeds on proximate composition and Artemia biomass production in salt ponds. Aquaculture, 286: 21 7-225.

Chepkirui-boit, V., Ngugi, C., Bowman, J., Oyoookoth, E., Rasowo, J., Mugo-bundi, J., \& Cherop, L. 2009. Growth performance, survival, feed utilization, and nutrient utilization of African catfish (Clarias gariepinus) larvae co-fed Artemia and a micro-diet containing freshwater atyid shrimp (Caridina nilotica) during weaning. Aquaculture Nutrition, No. doi: $10.1111 / \mathrm{j} .1365$ 2095. 2009.00737.x

Dhert, P., Rombaut, G., Suantika, G., \& Sorgeloos, P. 2001. Advancement of rotifer culture and manipulation techniques in Europe. Aquaculture, 200: 129-146.

Effendi, M.I. 2004. Metoda Biologi Perikanan. Catakan II. Yayasan Dewi Sri, Bogor, 157 pp.

Effendie, I. 1997. Biologi Perikanan. Yayasan Pustaka Nusatama. Bogor, 163 pp.

Evjemo, J.O., Reitan, K.I., \& Olsen, Y. 2001 . Copepods as food source in first feeding of marine fish larvae. Larvi' 01, Fish and shellfish larviculture symposium, Gent, Belgium, 2001.09.03-06.

Fermin, A.C. \& Bolivar, M.E.C. 1991 . Larval rearing of the Philippine freshwater catfish, Clarias macrocephalus (Gunther) fed live zooplankton and artificial diet: a preliminary study. Bamidgeh, 43: 87-94.

Garcia-Ortega, A., Verreth, J.A.J., Coutteau, P., Segner, H., Huisman, E.A., \& Sorgeloos, P. 1998. Biochemical and enzymatic characterization of decapsulated cysts and nauplii of the brine shrimp Artemia at different developmental stages. Aquaculture, 161: 501-514.

Gonzalez, A., Celada, J.D., González, R., García, V., Carral, J.M., \& Sáez-Royuela, M. 2008. Artemia nauplii and two commercial replacements as dietary supplement for juvenile signal cray fish, Pacifastacus leniusculus (Astacidae), from the on set of exogenous feeding under controlled conditions. Aquaculture, 281: 83-86. 
González, R., Celada, J.D., Carral, J.M., González, Á., Sáez Royuela, M., \& García, V. 2009. Decapsulated Artemia cysts as dietary supplement for juvenile cray fish (Pacifastacus leniusculus, Astacidae) at different food supply frequencies from the on set of exogenous feeding under controlled conditions. Aquaculture, 295: 200204.

Guillaume, J., Kaushik, S., Bergot, P., \& Metailler, R. 1999. Nutrition and feeding of fish crustaceans. UK: Praxis Publishing. xxiv +408 pp.

Handayani, S. 2006. Pengaruh penggunaan tepung kepala udang windu pada pakan buatan terhadap pertumbuhan dan kelangsungan hidup benih lobster air tawar (Cherax albertis). Skripsi. Jurusan Biologi FMIPA, Universitas Negeri Jakarta. Tidak dipublikasikan.

Hepher, W. \& Pruginin, Y. 1981. Commercial fish farming with special reference to fish culture in Israel. John Willey and Sons. New York, $261 \mathrm{pp}$.

Hogendoorn, H. 1979. Controlled propagation of the African catfish, (Clarias lazera): reproductive biology and field experiments. Aquaculture, 17: 323-333.

Huet, M. 1994. Textbook of fish culture: breeding and cultivation of fish ( $2^{\text {nd }}$ edition). Fishing News Books, Cambridge, 456 pp.

Hung, L.T., Tam, B.M., Cacot, P., \& Lazard, J. 1999. Larval rearing of the Mekong catfish, Pangasius bocourti (Pangasiidae, Siluroidei): Substitution of Artemia nauplii with live and artificial feed. Aquat. Living Resour., 12(3): 229-232.

Hung, L.T., Tuan, N.A., Cacot, P., \& Lazard, J. 2002. Larval rearing of the Asian catfish, Pangasius bocourti (Siluroidei, Pangasiidae): alternative feeds and weaning time. Aquaculture, 212: 115-127.

Juhariyah, D. 2005. Pengaruh pemberian nauplii Artemia sp., Moina sp., dan Tubifex sp. terhadap pertumbuhan dan kelangsungan hidup benih ikan Botia (Chromobotia macracanthus Bleeker). Skripsi. Fakultas Biologi, Univertas Nasional. Tidak dipublikasikan.

Leger,P., Bengtson, D.A., Simpson, K.L., \& Sorgeloos, P. 1986. The use and nutritional value of Artemia as a food source. Oceanogr. Mar. Biol. Annu. Rev. 24: 521 623.
Lim, C.L., Dhert, P., \& Sorgeloos, P. 2003. Recent developments in the application of live feeds in the freshwater ornamental fish culture. Aquaculture, 227: 319-331.

Marian, M.P. \& Pandian, T.J. 1984. Culture and harvesting techniques for Tubifex. Elsevier Science Publishers B.V., Amsterdam - Printed in The Netherlands 303. Aquaculture, 42: 303-315.

Meilisza, N. \& Hirnawati, R. 2010. Perbedaan rasio kombinasi pakan alami cacing darah dan Tubifex terhadap performansi berat dan panjang benih ikan botia (Chromobotia macracanthus). Prosiding Seminar Nasional Tahunan Hasil Penelitian Perikanan dan Kelautan Budidaya Perikanan. Tanggal 2-3 Desember 2010. Sekolah Tinggi Perikanan Jakarta, p. 211-215.

Mills, D., \& Lamnert, D. 2004. The Aquarium Fish Handbook. Grange Books. United Kingdom. $256 \mathrm{pp}$.

Millamena, O.M., Penaflorida, V.D., \& Subosa, P.F. 1990. The macronutrient composition of natural food organisms mass cultured as larval feed for fish and prawns. Isr. J. Aquac. Bamidgeh, 42(3): 77-83.

Mitra, G., Mukhopadhyay, P.K., \& Ayyappan, S. 2007. Biochemical composition of zooplankton community grown in freshwater earthen ponds: Nutritional implication in nursery rearing of fish larvae and early juveniles. Aquaculture, 272: 346-360.

Mulyanto. 1992. Lingkungan hidup untuk ikan. Departemen Pendidikan dan Kebudayaan, Jakarta. 138 pp.

Munilla-Moran, R., Starch, J.R., \& Barbout, A. 1990. The role of exogenous enzymes indigestion in cultured turbot larvae (Scophthalmus maximus L.). Aquaculture, 88: 337-350.

National Research Council (N.R.C). 1993. Nutrient Requirement of Fishes. National Academy Press, Washington D.C., 114 pp.

Ogata, Y., Tokue, Y., Yoshikawa, T., Hagiwara, A., \& Kurokura, H. 2011 . A Lacotian strain of the rotifer Brachionus angularis holds promise as a food source for small-mouthed larvae of freshwater fish in aquaculture. Aquaculture, 312: 72-76.

Pillay, T.V.R. 1990. Aquaculture-Principles and Practices. Fishing New Books, London, U.K. $575 \mathrm{pp}$.

Sari, O. 2003. Efisiensi produksi benih ikan botia (Chromobotia macracanthus Bleeker) 
yang diberi berbagai pakan alami. Skripsi. Fakultas Perikanan dan IImu Kelautan, Institut Pertanian Bogor.

Satyani, D.L. 2005. Kualitas air untuk ikan hias air tawar. Penebar Swadaya, Jakarta. vii + $80 \mathrm{pp}$.

Sorgeloos, P., Coutteau, P., Dhert, P., Merchie, G., \& Lavens, P. 1998. Use of brine shrimp, Artemia spp., in larval crustacean nutrition: a review. Rev. Fish. Sci., 6: 55-68.

Sorgeloos, P., Dhert, P., \& Candreva, P. 2001. Use of the brine shrimp, Artemia spp., in marine fish larviculture. Aquaculture, 200: 147-159.

Takeuchi, T. 2001. A review of feed development for early life stages of marine finfish in Japan. Aquaculture, 200: 203-222.

Verreth, J., Storch, V., \& Segner, H. 1987. A comparative studies on the nutritional quality of decapsulated Artemia cysts, microencapsulated egg diets, and enriched dry feeds for Clarias gariepinus (Burchell) larvae. Aquaculture, 63: 269-282.

Villegas, C.T. 1990. The effects on growth and survival of feeding water fleas (Moina macrocopa) and Rotifer (Brachionus plicatilis) to milk fish (Chanos chanos Forsskal) fry. Bamidgeh, 42: 10-17.

Ward A.J. \& Kumar, M.S. 2010. Bioconversion rate and optimum harvest intervals for Moina australiensis using digested piggery efûuent and Chlorellavulgaris as a food source. Bioresource Technology, 101: 2,210-2,216.

Watanabe, T., Kitajima, C., \& Fujita, S. 1983. Nutritional values of live organisms used in Japan for mass propagation of fish: A review. Aquaculture, 34: 115-143.

Yurnaliza. 2002. Senyawa khitin dan kajian aktifitas enzim microbial pendegradasinya. Digital Library, Universitas Sumatera Utara, $12 \mathrm{pp}$. 